\section{Bortkastet om brokk}

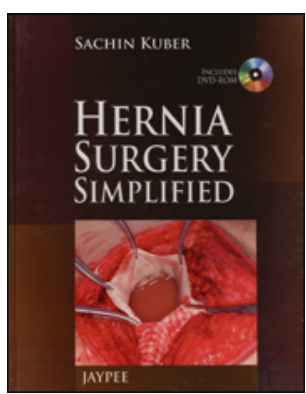

Sachin Kuber

Hernia surgery simplified

224 s, tab, ill. New Dehli: Jaypee Brothers

Medical Publishers, 2013. Pris USD 55

ISBN 978-93-5025-949-8

Denne boken er en katastrofe. Jeg burde avslutte bokanmeldelsen med dette, men det sterke utsagnet skylder vel en forklaring. I de fleste bøker jeg har kjøpt, fătt eller lånt, har jeg funnet noe som var av interesse, som presenterte noe på en ny eller annerledes måte, som ga dybdeinnsikt eller forklarte et tema fascinerende enkelt. I denne boken finner jeg ingen av delene.

Forfatteren introduseres som en «internationally acclaimed [sic]» ekspert innen brokkirurgi som har holdt foredrag over hele verden, inkludert i flere radioshow. Han praktiserer i Pune, India og er forfatter av mange artikler i aviser og blader, og har flere pasientinformative blogger.

Det er totalt 20 kapitler som skal presentere enkel herniekunnskap. Kapitlene har mange språklige og grammatiske feil, tydelige til og med for en vestlending uten medfødte engelskkunnskaper. Kapittel 3, Incidence, prevalence of hernia, er en reise i hvordan man kan (mis)bruke de mange variantene til powerpoint for å lage meningsløse grafer - her får man presentert søylediagram i pyramideform og kremmerhus, fordelinger mellom to grupper som smultringdiagram, og kakeplott $\mathrm{i}$ både to- og tredimensjonale former. Figurene har gjerne legender som sier «Ratio of inguinal hernia», fulgt av en annen figur som sier «Ratio in another survey», uten at vi får vite hvilken. Det er et sterilt fravær av referanser, og definisjonene er flytende - $\mathrm{i}$ et kapittel presenteres brokk hos barn i aldersgruppen 10-20 år (!), mens barnebrokk (kapittel 13) ikke er definert nærmere.

Da denne boken i sin helhet er om abdominale brokk, og et par slengere om lumbale hernier, skvetter jeg til da jeg på side 77 (kapitlet Diagnosis of hernia) får presentert et bilde av gastroskop i magesekken med tittelen Hiatus hernia. Så sant, så sant, men helt ute av kontekst.

Figurene er variable og dels med dårlig kvalitet. Flere bilder er sterkt pikselerte, muligens som følge av direkte klipp-og-lim fra nettet. Andre illustrasjoner er tydeligvis tegnet spesielt for boken. Her er det en god del underlige varianter og manglende proporsjoner: Ved beskrivelse av karanatomien i lysken er femoralarterien like tykk som femur, og vener er helt utelatt.

En CD som følger med, har jeg ikke puttet i datamaskinen i frykt for hva som da kan skje.

Oppsummert med forfatterens egne ord fra en av hans nettsider: «Our motto is loud and clear in serving hernia and other patients, a complete recovery from hernia. As all of know that hernia is a recurring problem in our society as well as worldwide. So to bring down rate of recurrence of the hernia is our prime goal. We always try hard to keep it below $2 \%$. Now it needs a lot of hard work.»

\section{Unik sykehistorie om visuell persepsjon}

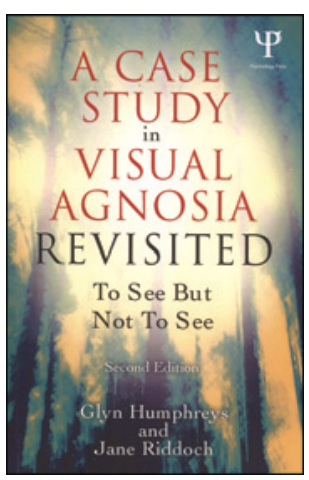

Glyn Humphreys, Jane Riddoch A case study in visual agnosia revisited To see but not to see. 2.utg. 142 s, ill. Hove: Psychology Press, 2014. Pris GBP 25 ISBN 978-1-84872-073-2

I denne boken, som nå kommer i andre utgave, beskriver forfatterne en pasients problemer med visuell gjenkjenning. John, en tidligere air force pilot, gjennomgikk i en alder av 60 år en akutt blindtarmsoperasjon. Etter oppvåkningen fra narkose kjente han ikke igjen noen av legene og heller ikke sin egen kone. Han hadde også store problemer med å identifisere objekter, hadde mistet fargediskrimineringen, leseferdigheten og orienteringsevnen. I de påfølgende 26 årene har han vært regelmessig testet (3-6 ganger årlig) av de to forfattere i samarbeid med en rekke andre vitenskapsfolk.

Mye av vår kunnskap om høyere visuelle funksjoner baserer seg på studier om denne pasienten og den grundige kartleggingen av hans manglende evne til å bearbeide visuelle stimuli. Inntil midten av forrige århundre har kunnskapen vært meget begrenset om visuell persepsjon, og man trodde at alt stort sett var lokalisert til synsbarken i oksipitallappen. I dag vet vi at en rekke områder i hjernen deltar i synsoppfatning som gjenkjennelse, bevegelse, farge og dybde.

Den første utgaven kom i 1987, og der viste man det pionerarbeidet som beskrev visuell agnosi. Denne nye utgaven er oppdatert med dagens viten om nevral lokalisasjon av synsfunksjon. Den er også illustrert med moderne undersøkelsesteknikker. Den lange observasjonstiden av pasienten ga mulighet til å registrere de kompensatoriske mekanismene og dynamikken som foregår mellom perseptuell bearbeiding og hukommelse.

Boken er i første rekke skrevet for nevropsykologer og synsforskere, men er også velegnet for alle som er interessert i visuell oppfatning. Den kan leses uten større forkunnskaper. Stilen er lett, presis, velformulert og samtidig varmt menneskelig. Referanselisten er god, og forfatterne er velkjente forskere med en imponerende publikasjonsliste.

Johns kasuistikk er blitt en klassiker og gir oss utmerket anledning å få innblikk i den fascinerende verdenen til vår viktigste sans: synet.

\section{Emilia Kerty}

Professor, Nevrologisk avdeling

Oslo universitetssykehus, Rikshospitalet 